\title{
Grape yield, and must compounds of 'Cabernet Sauvignon' grapevine in sandy soil with potassium contents increasing
}

\author{
Produção e composição do mosto de viníferas 'Cabernet Sauvignon' \\ cultivadas em solo arenoso com teores crescentes de potássio \\ Marlise Nara Ciotta ${ }^{\mathrm{I}}$ Carlos Alberto Ceretta ${ }^{\text {II }}$ \\ Lincon Oliveira Stefanello da Silva ${ }^{\text {II }}$ Paulo Ademar Avelar Ferreira ${ }^{\text {II }}$ \\ Claudia Kaehler Sautter ${ }^{\text {III }}$ Rafael da Rosa Couto ${ }^{\text {II }}$ Gustavo Brunetto ${ }^{\text {II }}$
}

\begin{abstract}
Content of exchangeable potassium $(K)$ in $t$ soil may influence on its content in grapevines leaves, grape yield, as well as, in must composition. The study aimed to assess the interference of exchangeable K content in the soil on its leaf content, production and must composition of 'Cabernet Sauvignon' cultivar. In September 2011, in Santana do Livramento (RS) five vineyards with increasing levels of exchangeable $K$ in the soil were selected. In the 2012/13 and 2013/14 harvests, the grape yield, yield components, total $K$ content in the leaves in full bloom and berries veraison were evaluated. Values of total soluble sugar (TSS), pH, total titratable acidity (TTA), total polyphenols and anthocyanins were evaluated in the must. Exchangeable $K$ content increase in soil with sandy surface texture increased its content in leaves collected during full flowering and in berries and must pH; however, it did not affect production of the 'Cabernet Sauvignon'.
\end{abstract}

Key words: foliar analysis, grape production, quality of the grape, Vitis vinifera.

RESUMO

$O$ potássio $(K)$ é um dos macronutrientes exigidos em maior quantidade pela videira, porém o seu incremento no solo pode não aumentar a produção de uva, mas pode modificar a sua composição. O trabalho objetivou avaliar a interferência do teor de $K$ trocável no solo sobre o seu teor na folha, produção e composição do mosto da cv. 'Cabernet Sauvignon'. Em setembro de 2011, em Santana do Livramento (RS), foram selecionados cinco vinhedos com níveis crescentes de $K$ trocável no solo. Nas safras 2012/13 e 2013/14, foi avaliada a produção de uva, os componentes de produção, o teor total de $K$ nas folhas no pleno florescimento e na mudança da cor das bagas. No mosto, foram avaliados os valores de sólidos solúveis totais (SST), pH, a acidez total titulável (ATT) e os totais de polifenóis e antocianinas. $O$ incremento do teor de $K$ trocável no solo aumentou o $K$ total nas folhas no pleno florescimento, nas bagas e a composição do mosto, mas não afetou a produção de uva da cv. 'Cabernet Sauvignon'.

Palavras-chave: análise foliar, produção, qualidade da uva, Vitis vinifera.

\section{INTRODUCTION}

Brazilian state of Rio Grande do Sul (RS) has approximately 50,000 hectares cultivated with vines, having the largest area with this crop in Brazil. From the 1970s, part of the RS state Campanha natural field soils were incorporated into wine grape (such as 'Cabernet Sauvignon') production systems, with grapes being used for fine wines production. This region is dominated by Paleaudalfs that have sandy surface texture and low fertility, whose nutrient content, such as exchangeable potassium $(\mathrm{K})$, is at medium or low availability rates (BRUNETTO et al., 2007). Therefore, the application of fertilizers, such as potassium-based ones, is essential during pre-planting and/or maintenance throughout the production cycle.

Plant $\mathrm{K}$ participates in substance synthesis, enzyme activation, photosynthesis and cell osmotic potential maintenance (KODUR et al., 2009). Although $\mathrm{K}$ is one of the most demanded macronutrients by vines and is exported in the highest quantities by bunches, it may not have a

\footnotetext{
IEmpresa de Pesquisa Agropecuária e Extensão Rural de Santa Catarina (EPAGRI), Florianópolis, SC. Estação Experimental de São Joaquim (EESJ), Rua João Araújo Lima, 102, CP 81, 88600-000, São Joaquim, SC, Brasil. E-mail: mciotta@gmail.com. Corresponding author.

IIDepartamento de Solos, Universidade Federal de Santa Maria (UFSM), Santa Maria, RS, Brasil.

IIIDepartamento de Tecnologia de Alimentos, Universidade Federal de Santa Maria (UFSM), Santa Maria, RS, Brasil. Received 04.01.15 Approved 02.16.16 Returned by the author 05.04.16 CR-2015-0472.R1
} 
direct impact on grape yield and its components, such as the number of bunches and the weight of 100 berries (BOONTERM et al., 2010; SCHREINER et al., 2012). The reason for this is because its functions are related to plant metabolism. However, when $\mathrm{K}$ is absorbed and transported within the plant, it can be diagnosed on the leaves, particularly if collected during flowering, since it is a period in which they are growing and having intensive cell division. In addition, it can also be diagnosed in leaves collected during berries color changing (STELLACCI et al., 2010). However, analysis of leaves collected during berries color changing not always indicates vines $\mathrm{K}$ content, because part of the nutrient can be redistributed from leaves to other organs in growth, such as berries or reserve organs, such as more than a year old branches and roots (TAGLIAVINI \& SCANDELLARI, 2013). Conversely, potassium fertilizers application in vineyards and, consequently, its exchangeable form increase in the soil can affect must composition, sugars content $(90 \%$ of them being represented by total soluble solids - TSS), $\mathrm{pH}$ values and total values of titratable acidity (TTA), polyphenols and anthocyanins are used to diagnose must composition (BOONTERM \& SILAPAPUN, 2013).

High $\mathrm{K}$ levels in berries, and consequently in the must, can cause sugars reduction, impairing must fermentation (WALKER \& BLACKMORE, 2012), causing must $\mathrm{pH}$ elevation and TTA decrease, which increases wine oxidation susceptibility (MPELASOKA et al., 2003). However, in vines grown in most of the wine-growing regions of Brazil, including the RS Campanha, there are few studies on the production influence of $\mathrm{K}$ content increase in the soil, and especially in the must composition, which may impact wine composition. The study aimed to assess the interference of exchangeable $\mathrm{K}$ content in the soil on its leaf content, production and must composition of 'Cabernet Sauvignon' cultivar.

\section{MATERIALS AND METHODS}

The experiment was conducted in Santana do Livramento, RS Campanha region, Brazil, in 2012/13 and 2013/14 harvests. The soil of the vineyards was a Paleaudalf. Climate, according to Koppen classification, is humid subtropical, Cfa2 type, which is characterized by mild temperatures and rain with little variation throughout the year. Average annual rainfall is $1,600 \mathrm{~mm}$, the warmest month average temperature (January) is $23.8^{\circ} \mathrm{C}$ and the coldest month average temperature (July) is $12.4^{\circ} \mathrm{C}$.
Treatments consisted of five vineyards, with increasing levels of exchangeable $\mathrm{K}$ (extracted by Mehlich-1) in the soil: 66, 73, 86, 95 and $111 \mathrm{mg}$ $\mathrm{kg}^{-1}$, constructed over the years by potassic fertilizers. All the vineyards showed organic matter contents next to $6.0 \mathrm{~g} \mathrm{~kg}^{-1}$, water $\mathrm{pH}$ next to 5.70 , low exchangeable $\mathrm{Ca}$ contents $(1.50 ; 0.61 ; 1.19 ; 0.85$; $\left.1.40 \mathrm{cmol}_{\mathrm{c}} \mathrm{kg}^{-1}\right)$, intermediate exchangeable $\mathrm{Mg}$ contents $\left(0.84 ; 0.400 .78 ; 0.56 ; 0.68 \mathrm{cmol}_{\mathrm{c}} \mathrm{kg}^{-1}\right)$ and high $\mathrm{P}$ content available in the soil $(30.7 ; 55.4 ; 22.2$; $77.2 ; 46.3 \mathrm{mg} \mathrm{kg}^{-1}$ for the soil classified as class 4, according to the clay content) (CQFS-RS/SC, 2004), respectively, for each vineyard. 'Cabernet Sauvignon' was the cultivar, espalier was the conduction system and vines had the same number of gems in winter pruning. The experimental design was of randomized blocks with three repetitions, and each plot was formed for twenty plants, with ten central plants being assessed. In 2012/13 and 2013/14 harvests, during vines full flowering (October) and berries color changing (January), two leaves opposed to the first bunch were collected, in each of the 10 central plants in each plot. Leaves were dried in an oven with forced air at $65^{\circ} \mathrm{C}$, milled and prepared for total $\mathrm{K}$ content analysis (TEDESCO et al., 1995).

In February of 2012/13 and 2013/14

harvests, during grape maturation, number of bunches per plant was counted. Subsequently, bunches were weighed using a digital scale. Five bunches were randomly separated, and 100 berries were collected at the top, middle and bottom of each bunch, being weighed on a digital scale. Berries were grounded and total $\mathrm{K}$ content and TSS values were determined in the must using a digital refractometer; $\mathrm{pH}$ value was determined using a digital potentiometer and TTA was determined by titration with $\mathrm{NaOH} 0.1 \mathrm{~mol} \mathrm{~L}^{-1}$ (BRUNETTO et al., 2009). Furthermore, total anthocyanins analysis was performed by absorbance reading at $540 \mathrm{~nm}$. Results were expressed in malvid in $\mathrm{mg} \mathrm{L}^{-1}$. In addition, total polyphenols concentration was analyzed by reaction with Folin Ciocalteu. Absorbance reading was conducted at a wavelength of $765 \mathrm{~nm}$, with results being expressed in $\mathrm{mg} \mathrm{L}^{-1}$. Total $\mathrm{K}$ content was also determined (TEDESCO et al., 1995).

Results were statistically analyzed through orthogonal contrasts, as follows: $\mathrm{C} 1$ contrast: Vineyard 1 comparison with vineyard 2; C2 contrast: Vineyard 1 comparison with vineyard 3; C3 contrast: Vineyard 1 comparison with vineyard 4; $\mathrm{C} 4$ contrast: Vineyard 1 comparison with vineyard 5; C5 contrast: Vineyard 2 comparison with vineyard 3; C6 contrast: Vineyard 2 comparison with vineyard 4; C7 contrast: Vineyard 2 
comparison with vineyard 5; C8 contrast: Vineyard 3 comparison with vineyard 4; C9 contrast: Vineyard 3 comparison with vineyard 5 and $\mathrm{C} 10$ contrast: Vineyard 4 comparison with vineyard 5. In 2012/13 and 2013/14 harvests, grape production parameters average, 100 berries weight, total $\mathrm{K}$ content in the leaves, berries $\mathrm{K}$ and yield components were subjected to Principal Component Analysis (PCA).

\section{RESULTS AND DISCUSSION}

Production and its components and total $\mathrm{K}$ content in leaves and berries

In the 2012/13 harvest, grape production has not statistically differed between vineyards (Table 1). This is possibly because water availability in the soil, especially during the vegetative and

Table 1 - Yield and its components in the total $\mathrm{K}$ content in berry, $\mathrm{K}$ exported by berries and total $\mathrm{K}$ content in leaves in 'Cabernet Sauvignon', grown in vineyards with increasing levels of exchangeable $\mathrm{K}$ in the soil and significance of mean comparisons by contrasts.

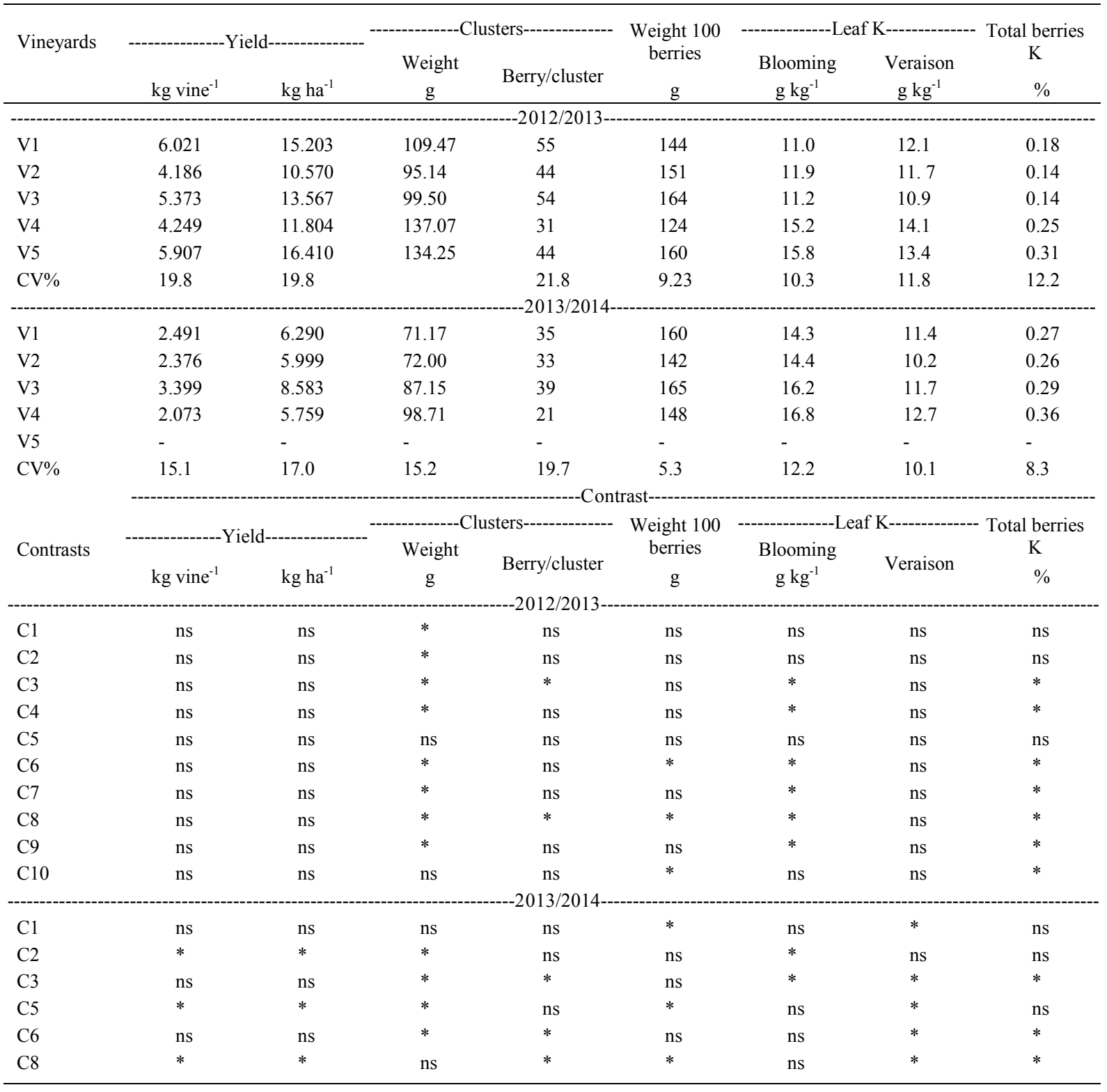

*significant difference between the wines involving contrast $(\mathrm{P}<0.05)$.

$\mathrm{ns}=$ not significant contrasts. 
productive period (August to February), was sufficient, favoring nutrients supply, including $\mathrm{K}$ in particular, by diffusion to vine roots outer surface. Subsequently, the K ion may have been absorbed by the plants through specialized channels, following an electrochemical gradient (KODUR et al., 2009). Inside the plant, $\mathrm{K}$ transport occurred via xylem and phloem, and was accumulated in growth organs, with higher nutrient demand (KODUR et al., 2009). Conversely, the other production components significantly varied between vineyards. Average bunch mass was larger in vineyards 4 and 5 in relation to vineyards 1, 2 and 3 (Table 1). Number of bunches per plant was higher in vineyards 1 and 3 in relation to the vineyard 4, while there was no significant difference in the number of bunches per plant in other vineyards. Vineyards 2 and 3, which were not statistically different from each other, had the highest 100 berries weight in relation to the vineyard 4, while there was no difference in this parameter between vineyard land the others.

$\mathrm{K}$ content in the leaves collected during vines full flowering in the 2012/13 harvest was higher in vineyards 4 and 5 in relation to the other vineyards (Table 1). This can be attributed to exchangeable $\mathrm{K}$ contents in the soil, 95 and $111 \mathrm{mg} \mathrm{kg}^{1}$, respectively, higher than contents observed in vineyards 1, 2 and 3 . Thus, higher K supply, absorption and accumulation in plants are expected, especially in accumulation organs during the summer period, such as leaves that are in intensive cell division, becoming nutrient drainers (TAGLIAVINI \& SCANDELLARI et al., 2013). Thus, the absorbed nutrient supplies the physiological needs and forms reserves in the plant (BRUNETTO et al., 2006). However, total $\mathrm{K}$ content in the leaves has not varied between vineyards during berries color changing. Vine nutrient content diagnosis is not always correct by the analysis of leaves collected during berries color changing (TAGLIAVINI\& SCANDELLARI et al., 2013), such as $\mathrm{K}$ in vines, because the nutrient in ionic form can be redistributed from leaves to other organs in growth, such as bunches, or in lower amounts to other nutrient reserve organs, such as roots or branches that are more than one year old (BRUNETTO et al., 2006).

The highest total $\mathrm{K}$ content in berries was observed in the vineyard 5, followed by vineyard 4 . The total K content in the grapes of the other vineyards has not differed in the 2012/13 harvest (Table 1). This can be attributed to the highest exchangeable potassium availability in the soil of vineyards 4 and 5 , which was of 95 and $111 \mathrm{mg} \mathrm{kg}^{-1}$, respectively. Part of the absorbed K may have been transported to bunches, especially berries, which during the cycle increase the mass and become nutrient drainers, especially K (KODUR et al., 2009). In addition, part of the $\mathrm{K}$ accumulated in other vine organs, like leaves, especially in the vineyards with higher exchangeable $\mathrm{K}$ content in soil, as diagnosed in the leaves collected during full flowering in the vineyard 4 , may have been redistributed from leaves to berries in growth (TECCHIO et al., 2011; KODUR, 2011).

In the 2013/14 harvest, vineyard 3 showed the highest grape production in relation to vineyards 1 , 2 and 4 (Table 1). This result may be associated with other production components, such as bunch number and mass. Leaf $\mathrm{K}$ content during full flowering was lower in vineyard 1 in relation to vineyards 3 and 4 . In color changing, $\mathrm{K}$ content in the leaves was lower in vineyard 2 . Consequently, $\mathrm{K}$ content in the berry was higher in the vineyard 4, differentiated from the others.

Grape production in the 2012/13 harvest, in all vineyards, was higher than that observed in the 2013/14 harvest (statistic not shown) (Table 1). This possibly occurred as a result of rainfall appropriate volume and distribution in the 2012/13 harvest, which favored the K supply, among other nutrients, to the vines. With the appropriate rainfall amount and distribution, in addition to increasing water and nutrients availability to the vines, cover crops who lived around the vineyards growth was probably favored, providing higher nutrient absorption, with $\mathrm{K}$ among them. At the end of the cycle, with cover crop species shoot senescence or cutting, waste was deposited on the soil surface. During decomposition, $\mathrm{K}$ and other nutrients have been released into the soil, especially in the soil upper layers, where thinner roots that are responsible for the increased nutrient absorption by vines are observed (KODUR et al., 2009). In addition, vines in production have roots in deeper soil layers, which can also contribute to $\mathrm{K}$ absorption, although probably in lower amounts (KODUR et al., 2009). In the 2013/14 harvest, rainfall volumes above normal for the region (over $100 \mathrm{~mm}$ ) were observed, which extended from September 2013 until March 2014 (data not shown). This possibly stimulated the incidence of fungal diseases in bunches, which was reflected in lower grape production compared to the previous harvest.

\section{Must composition}

In the 2012/13 harvest, must TSS content was higher in the vineyard 1, in relation to all other vineyards (Table 2). In part, this may be explained by the lower mass of 100 berries observed in vineyard 1 (Table 2), which gives higher TSS concentration in the berry. In vineyards 2 and 4, 
Table 2 - Total soluble solids (TSS), pH, total titratable acidity (TTA), total polyphenols and anthocyanins in the must of 'Cabernet Sauvignon', in vineyards with increasing levels of exchangeable $\mathrm{K}$ in the soil and significance of mean comparisons by contrasts.

\begin{tabular}{|c|c|c|c|c|c|}
\hline Vineyards & $\begin{array}{c}\text { TSS } \\
\left({ }^{\circ} \text { Brix) }\right.\end{array}$ & $\mathrm{pH}$ & $\begin{array}{c}\text { TTA } \\
\left(\text { meq L }^{-1}\right)\end{array}$ & $\begin{array}{l}\text { Total polyphenols } \\
\qquad\left(\mathrm{mg} \mathrm{L}^{-1}\right)\end{array}$ & $\begin{array}{c}\text { Anthocyanins } \\
\left(\mathrm{mg} \mathrm{L}^{-1}\right)\end{array}$ \\
\hline \multicolumn{6}{|c|}{-------------------------------------------- } \\
\hline V1 & 19.8 & 3.85 & 46.67 & 44.8 & 64.8 \\
\hline $\mathrm{V} 2$ & 18.2 & 3.83 & 45.00 & 96.0 & 79.2 \\
\hline V3 & 18.0 & 3.80 & 51.67 & 64.1 & 70.9 \\
\hline V4 & 18.3 & 4.14 & 48.33 & 70.4 & 77.5 \\
\hline V5 & 17.1 & 4.04 & 56.67 & 57.1 & 60.1 \\
\hline CV\% & 3.2 & 1.5 & 4.7 & 9.6 & 6.0 \\
\hline V1 & 16.3 & 3.94 & 14---------- & 50.3 & 70.4 \\
\hline $\mathrm{V} 2$ & 12.3 & 3.86 & 41.67 & 65.1 & 64.3 \\
\hline V3 & 11.9 & 3.56 & 25.00 & 69.2 & 61.0 \\
\hline V4 & 10.7 & 4.35 & 45.00 & 88.3 & 114.2 \\
\hline V5 & nd & nd & nd & nd & nd \\
\hline $\mathrm{CV} \%$ & 9.9 & 5.9 & 18.0 & 9.7 & 13.1 \\
\hline Vineyards & $\begin{array}{c}\text { TSS } \\
\left({ }^{\circ} \text { Brix) }\right.\end{array}$ & $\mathrm{pH}$ & $\begin{array}{c}\text { TTA } \\
\left(\text { meq } L^{-1}\right)\end{array}$ & $\begin{array}{l}\text { Total polyphenols } \\
\qquad\left(\mathrm{mg} \mathrm{L}^{-1}\right)\end{array}$ & $\begin{array}{l}\text { Anthocyanins } \\
\left(\mathrm{mg} \mathrm{L}^{-1}\right)\end{array}$ \\
\hline $\mathrm{C} 1$ & * & ns & 13---------- & $*$ & $*$ \\
\hline $\mathrm{C} 2$ & * & ns & * & * & ns \\
\hline $\mathrm{C} 3$ & * & $*$ & $\mathrm{~ns}$ & * & $*$ \\
\hline $\mathrm{C} 4$ & $*$ & $*$ & * & $*$ & ns \\
\hline $\mathrm{C} 5$ & ns & $\mathrm{ns}$ & $*$ & * & $*$ \\
\hline C6 & ns & * & $\mathrm{ns}$ & * & ns \\
\hline $\mathrm{C} 7$ & $*$ & $*$ & $*$ & * & $*$ \\
\hline $\mathrm{C} 8$ & ns & * & $\mathrm{ns}$ & ns & ns \\
\hline C9 & ns & $*$ & $*$ & ns & $*$ \\
\hline $\mathrm{C} 10$ & $*$ & $\mathrm{~ns}$ & $*$ & $*$ & $*$ \\
\hline $\mathrm{C} 1$ & $*$ & ns & ns & $*$ & ns \\
\hline $\mathrm{C} 2$ & * & ns & $*$ & $*$ & ns \\
\hline $\mathrm{C} 3$ & * & ns & ns & $*$ & * \\
\hline $\mathrm{C} 5$ & ns & ns & $*$ & ns & ns \\
\hline C6 & ns & * & $\mathrm{ns}$ & * & $*$ \\
\hline $\mathrm{C} 8$ & ns & $*$ & $*$ & $*$ & $*$ \\
\hline
\end{tabular}

*significant difference between the wines involving contrast $(\mathrm{P}<0.05)$. ns $=$ not significant contrasts.

nd $=$ not dtermined

higher TSS contents were observed in relation to the vineyard 5 must. In part, this can be attributed to the higher mass of 100 berries observed in vineyard 5 , which indicates high peel/pulp correlation. That is, sugars dilution in relation to vineyards 2 and 4 . High $\mathrm{K}$ content in the berry can also be explained, which influences sugars accumulation, since after the bunch color changing phase, $\mathrm{K}$ tends to be accumulated in the fruit, decreasing sugars concentration (CONDE et al., 2007).
The $\mathrm{pH}$ value in vineyards 4 and 5 must has not statistically differed from each other, and were higher than the values observed in the must of the other vineyards in the 2012/13 harvest (Table 2). Higher $\mathrm{pH}$ values in the must of vineyards 2 and 5 may be attributed in part to the higher $\mathrm{K}$ content in the berries (Table 2). Higher K contents in the berries can promote $\mathrm{pH}$ values increase in must through acid protons $\left(\mathrm{H}^{+}\right)$stoichiometric exchange by $\mathrm{K}$ ion. $\mathrm{K}$ bitartrate is thus formed, 
which is a salt that can be precipitated in the wine, damaging its quality, modifying the taste, and determining higher oxidation power, i.e., lower wine storage time (WALKER \& BLACKMORE, 2012). These results corroborate with those obtained by BOONTERM \& SILAPAPUN (2013), who observed must $\mathrm{pH}$ value increase with $\mathrm{K}$ application in the soil of the vineyards. In general, must $\mathrm{pH}$ values observed in the present study may be considered high, because $\mathrm{pH}$ values higher than 3.50 preclude must fermentation, altering organoleptic characteristics, color, flavor and wine oxidation power (MPELASOKA et al., 2003; ROGIERS et al., 2006).

TTA in the must of vineyard 5 was higher than that observed in the must of the other vineyards in the 2012/13 harvest. Vineyard 3 must showed higher TTA than that observed in vineyards 1 and 2 . Such results may be related to higher $\mathrm{pH}$ values in the must of vineyards 4 and 5 , caused by higher $\mathrm{K}$ content in the grapes these vineyards.

The highest total polyphenols content in the 2012/13 harvest was observed in the must of vineyard 2, and the lowest in the must of vineyard 1, with no statistical difference in the total polyphenol contents checked among vineyards 3 and 4 and among vineyards and 3 and 5 (Table 2). These results corroborate with those obtained by BOONTERM \& SILAPAPUN (2013) in a vineyard in Southern China, where K effects on the soil over total polyphenol content were only observed when high doses of $\mathrm{K}$ and $\mathrm{N}$ were applied.

Total anthocyanin content in the must of the 2012/13 harvest was higher in the vineyards 2 and 4 compared to the other vineyards (Table 2). Vineyard 5 total anthocyanin content has not differed from vineyard 1 in the 2012/13 harvest. One possible explanation for the lower total anthocyanins content in the must of Vineyard 5 may be the increased $\mathrm{K}$ availability in the soil, which increased $\mathrm{K}$ concentration on berries. In addition higher $\mathrm{pH}$ value was also observed, which affects these compounds ionization (CONDE et al., 2007). In vineyards with lower production, fewer bunches and increased plant growth, anthocyanins distribution from berries to parts of the plant in growth may occur, such as branches and leaves, and there may be decreased enzyme activity, which regulate anthocyanins synthesis (BRUNETTO et al., 2009).

In the 2013/14 harvest, the must of vineyard 1 had the highest SST value. In the other vineyard musts, values have not statistically differed. Must $\mathrm{pH}$ value was higher in the vineyard
4. These results corroborate with those obtained in the previous harvest (2012/13), where the highest K content in the soil of vineyard 4 increased nutrient content in the berry and must $\mathrm{pH}$ value. Vineyard 3 had the lowest TTA $\left(25 \mathrm{meq} \mathrm{L}^{-1}\right)$ in relation to the others, which have not showed statistical difference. Total polyphenols and anthocyanins content in the 2013/14 harvest were higher in the vineyard 4.

In the 2012/13 harvest, PCA showed that factor 1 separated vineyards 1 and 2, explaining $73.79 \%$ of the data (Figure 1a). Variables that contributed the most were production, weight of 100 berries and total $\mathrm{K}$ content in leaves during full flowering and in the berry. In addition, must components also contributed, such as TSS, and total polyphenols and anthocyanins. This result showed that the $\mathrm{K}$ content in the soil influences the vast majority of production components, plant nutritional status and must composition. Factor 2 separated the other vineyards and explained $21.25 \%$ of the results. Must TTA was the variable that most contributed. In the 2013/14 harvest, PCA shows that factor 1 separated vineyards 3 and 4 , explaining $62.7 \%$ of the results (Figure $1 \mathrm{~b}$ ). Grape production, in addition to must components, TTA, $\mathrm{pH}$ and anthocyanins, were the variables that contributed the most to this result. Vineyards 1 and 2 were separated by factor 2 , which explained $36.16 \%$ of the data. Variables that contributed the most were the mass of 100 berries and total K content in the leaves during full flowering and in the berry. In addition, must components, such as TSS and total polyphenols also contributed.

$\mathrm{K}$ content in the berry, $\mathrm{K}$ in the leaves in full flowering and TSS values have a high correlation among them (Figures 1a, 1b). Conversely, production was not highly related with these attributes. One possible explanation is that, in vineyards where there was higher $\mathrm{K}$ availability in the soil, nutrient content increase in the leaves was not diagnosed (Table 2).

\section{CONCLUSION}

Exchangeable $\mathrm{K}$ content higher in soil with sandy surface texture increased its content in the leaves collected during full flowering and berries. Must composition was changed, and the $\mathrm{pH}$ was higher in vines grown in the soil with higher $\mathrm{K}$ content. The highest SST content in the must occurred in the vineyard with the lowest $\mathrm{K}$ content in the soil. However, K contents in the soil have not affected 'Cabernet Sauvignon' cultivar production. 

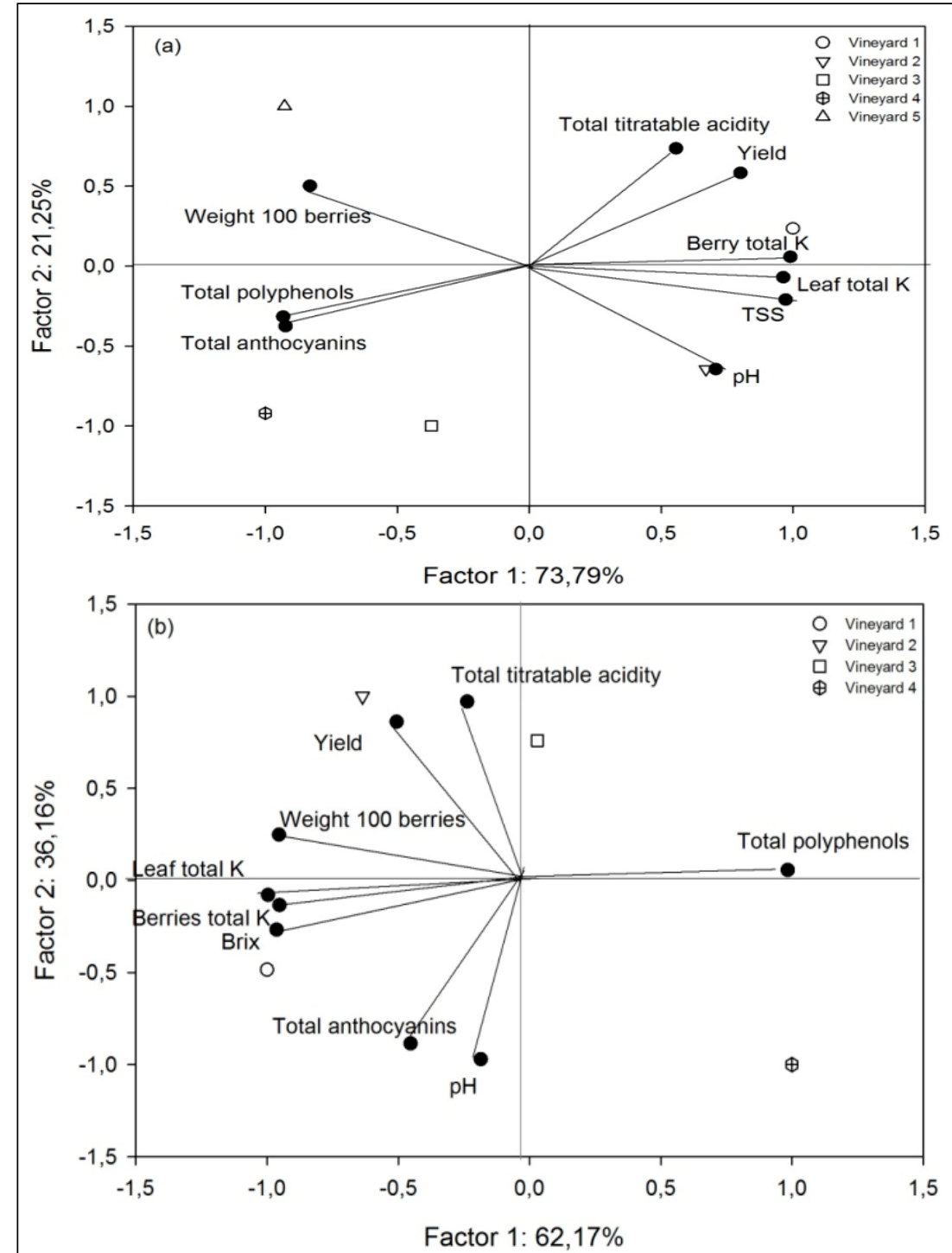

Figure 1 - Principal Component Analysis (PCA) considering weight of 100 berries, total content of $\mathrm{K}$ in e leaves, total content of $\mathrm{K}$ in berries, $\mathrm{pH}$, titratable acidity (TTA), total soluble solids (TSS), total polyphenols, total anthocyanins in 2012/13 (a) and 2013/14 (b) in the 'Cabernet Sauvignon' grown in soils with increasing levels of exchangeable K.

\section{ACKNOWLEDGEMENTS}

The authors thank the support to the "Vinícola Almaden', in Santana do Livramento (RS), and financial resources of Fundação de Amparo à Pesquisa do Estado do Rio Grande do Sul (FAPERGS), Conselho Nacional de Desenvolvimento Científico e Tecnológico (CNPq) e Coordenação de Aperfeiçoamento de Pessoal de Nível Superior (CAPES).

\section{REFERERENCES}

BOONTERM, C.W. et al. Effects of nitrogen, potassium fertilizer, and clusters per vine on yield and anthocyanin content in 'Cabernet Sauvignon' grape, Suranaree. Journal Science Technology, v.17, n.2, p.155-163, 2010
BOONTERM, V.; SILAPAPUN, A. Effects of nitrogen potassium fertilizers and clusters per vine on yeld and anthocyanin content in 'Cabernet Sauvignon' grape. Acta Horticulturae, v.984, p.435-442, 2013.

BRUNETTO, G. et al. Recovery and distribution of supplied nitrogen to young grapevines. Pesquisa Agropecuária Brasileira, v.41, p.1299-1304, 2006. Available from: <http://www.scielo. br/scielo.php?pid $=$ S0100-04X2006000800013\&script $=$ sci arttext>. Accessed: Mar. 01, 2015. doi: 10.1590/S0100204X2006000800013.

BRUNETTO, G. et al. Application of nitrogen in grapevines in the campaign of the Rio Grande do Sul: productivity and chemical characteristics of the grape must. Ciência Rural, v.37, n.2, p.389-393, 2007.

Ciência Rural, v.46, n.8, ago, 2016. 
BRUNETTO, G. et al. Produção e composição química da uva de videiras Cabernet Sauvignon submetidas à adubação nitrogenada. Ciência Rural, v.39, p.2035-2041, 2009.

CQFS (COMISSÃO DE QUÍMICA E FERTILIDADE DO SOLO RS/SC). Manual de adubação e calagem para os Estados do Rio Grande do Sul e de Santa Catarina. 10.ed. Porto Alegre, SBCS Núcleo Regional Sul/UFRGS, 2004. 400p.

CONDE, C. et al. Biochemical changes throughout grape Berry development and fruit and wine quality. Food, v.1, p.1-22, 2007. Available from: $<$ http://www.scielo.br/scielo.php?script $=$ sci nlinks\&ref $=000091 \&$ pid $=$ S0100-204X201200020000800006\&ln $\mathrm{g}=\mathrm{en}>$. Accessed: Mar. 01, 2015.

KODUR, S. Effects of juice $\mathrm{pH}$ and potassium on juice and wine quality, and regulation of potassium in grapevines through rootstocks (Vitis): a short review. Vitis, v.50, p.1-6, 2011.

KODUR, S. et al. Accumulation of potassium in grapevine rootstocks (Vitis) as affected by dry matter partitioning, root traits and transpiration. Australian Journal of Grape and Wine Research, v.16, p.273-282, 2009.

MPELASOKA, B.S.et al. A review of potassium nutrition in grapevines with special emphasis on berry accumulation. Australian Journal of Grape and Wine Research, v.9, p.154-168, 2003.

ROGIERS, S.Y. et al. Mineral sinks within ripening grape berries (Vitis vinifera L.). Vitis, v.45, n.3, p.115-123, 2006. Available from: <http://www.vitis-vea.de/admin/volltext/e052759.pdf>. Accessed: Mar. 10, 2015.

SCHREINER, R.P. et al. N, P, and K supply to pinot noir grapevines: impact on vine nutrient status, growth, physiology, and yield. American Journal of Enology and Viticulture, v.64, n.4, p.26-38, ajev-2012.

STELLACCI, A.M. et al. Relationships between soil characteristics and leaf nutrient concentrations in grapevine. Acta Horticulturae, v.868, p.135-142, 2010.

TAGLIAVINI, M.; SCANDELLARI, F. Methodologies and concepts in the study of nutrient uptake requirements and partitioning in fruit trees. Acta Horticulturae, v.984, p.47-56, 2013.

TECCHIO, M.A. et al. Nutrients extraction by vine "niagara rosada' grafted on different rootstocks. Revista Brasileira Fruticultura, v. spec, p.736-742, 2011. Available from: $<$ http://www.scielo.br/pdf/rbf/v33nspe1/a103v33nspe1.pdf $>$. Accessed: Feb. 20, 2015

TEDESCO, M. et al. Análise de solo, plantas e outros materiais. 2.ed. Porto Alegre-RS: Departamento de Solos, UFRGS, 1995. 174p.

WALKER, R.R.; BLACKMORE, D.H. Potassium concentration and $\mathrm{pH}$ inter-relationships in grape juice and wine of Chardonnay and Shiraz from a range of rootstocks in diferents environments. Australian Journal of Grape and Wine Research, n.18, p.183-193, 2012. 